perspective evaluation of State Polish Accreditation Commission III term of office]. Działalność Państwowej Komisji Akredytacyjnej w latach 2008-2011, III Kadencja, Warszawa: Polska Komisja Akredytacyjna, pp. 112-117 [in Polish].

4. Polska komisja akredytacyjna [Polish Accreditation Commission]. URL: www.pka.edu.pl/ (data zvernennia: 20.06.2019) [in Polish].

5. Rozporządzenie Ministra Nauki i Szkolnictwa Wyższego z dnia 5 października 2011 r. w sprawie warunków prowadzenia studiów na określonym kierunku i poziomie kształcenia [Regulation of the Minister of Science and Higher Education of October 5, 2011 regarding the conditions for conducting studies at a given field and level of education], p. 4-5. URL: http://www.bip.nauka.gov.pl/_gAllery/15/61/15616/20111012_stud_okres_kier.pdf (data zvernennia: 10.07.2019) [in Polish].

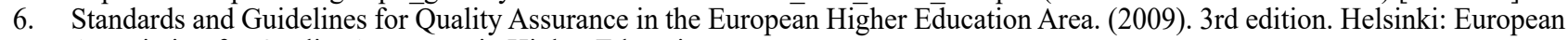
Association for Quality Assurance in Higher Education.

7. System jakości kształcenia UMSC. System zapewnienia jakości kształcenia. [UMSC Education Quality System. Education Quality Assurance System.] URL: https://www.umcs.pl/pl/system-zapewnienia-jakosci-ksztalcenia (data zvernennia: 11.09.2019) [in Polish].

8. Szkoly wyzsze i ich finanse w 2014 r. Informacje i opracowania statystyczne. (2015). [Higher schools and their finances in 2014. Information and statistical data]. Warszawa: Glowny urzad statystyczny. 242 p. URL: http://www.sta.gov.pl (data zvernennia: 22.06.2019) [in Polish].

9. Tutko M. (2012). Zapewnianie jakości kształcenia w świetle reformy szkolnictwa wyższego [Ensuring the quality of education in the context of higher education reform]. Zróżnicowaniei zmienność społecznego świata. Ewa Bogacz-Wojtanowska, Wiesław Gumuła, Sławomir Rębisz (eds). Kraków: Wydawnictwo Uniwersytetu Jagiellońskiego [in Polish].

10. Uchwała Nr XXIV - 2.8/16 Senatu Uniwersytetu Marii Curie-Skłodowskiej w Lublinie z dnia 23 listopada 2016 r. [Resolution]. URL: https://phavi.umcs.pl (data zvernennia: 12.10.2019) [in Polish].

11. Hryshchuk Yu. (2018). Systema vnutrishnoho zabezpechennia yakosti vyshchoi osvity: Dosvid respubliky Polshcha [Internal quality assurance system of higher education: experience of the Republic of Poland]. Osvitolohiia. №7. P. 152-156. doi.org/10.2 8925/2226-3012.2018.7.152156 [in Ukrainian].

12. Standards and Guidelines for Quality Assurance in the European Higher Education Area (ESG). K.: CS Ltd., 2015. 32 p.

Havran M. I., Shainer H. I. The education activities quality assurance system at higher education institutions in Poland in the context of developing European Higher Education Area

The article deals with the problem of ensuring the quality of educational activities of higher education institutions in Poland in the context of developing European Higher Education Area. The importance and topicality of the problem as well as the need to study foreign experience are substantiated. The authors emphasise the importance of implementing and developing educational activities quality assurance systems, as the quality assurance and enhancing educational services are considered as one of the priority tasks in the education documents signed in the context of developing European Higher Education Area. The basic directions of educational activities quality assurance implementing in higher education institutions of Poland are highlighted. The basic principles of the development of the higher education quality assurance system at Polish higher schools are substantiated. The quality of educational activities and educational services in the educational space of Poland is found out to be regulated and ensured by both an external system (the Polish Accreditation Commission) and well-developed internal systems for ensuring the quality of educational activities. The structure and functional features of the internal quality assurance system of one of the leading Polish universities are analysed. The study concludes that one of the priority areas of providing quality educational services is the awareness of the need to develop a culture of quality education, focused on the desire of society to obtain education only of high quality. The directions of improving educational activities quality assurance system of Ukrainian higher education institutions in the context of developing European Higher Education Area are substantiated, among others there is the development and implementation of a comprehensive internal system of educational activities quality assurance along with guaranteeing its proper functioning and recognizing the importance of this process.

Key words: educational activities quality assurance system, quality of higher education, internal system, external system, culture of quality education, higher education institutions of Poland, European Higher Education Area.

\author{
UDC 378.147.157 \\ DOI https://doi.org/10.31392/2311-5491/2019-70.13
}

Havrylenko K. M.

\title{
DISTANCE LEARNING IN THE MODERN SYSTEM OF HIGHER EDUCATION
}

Distance education is a new type of learning technologies, which appeared on demand of modern society and due to the development of new computer technologies. The main goal of distance learning is not to issue a university diploma but to satisfy individual needs in education and self-development.

In this paper, we tried to determine the place of distance learning in the whole educational system of modern higher institutions and consider the main advantages and disadvantages of distance learning technologies implementation in the development of professional knowledge and competencies. The importance of obtaining relevant final results of distance education for a final user is being discussed, and the professional knowledge and skills training for satisfying individuals'needs as well as the social and economic demands for them have been outlined. The paper draws attention to the fact that education is dependent on the unified education system of a higher institution and there is a significant period between the knowledge acquired in the process of education and its final results in the form of professional skills and competencies development.

The main goals of distance education planning have been analyzed as an important means of successful professional training. It has been stressed that educational planning should be designed for providing a learner with an opportunity to apply his potential ensured by the training materials and supported by consulting assistance for individual needs. 
The main requirements for the statement of distance education goals and objectives have been determined as well and the importance of learning goals correspondence from the social and professional background of the future specialist has been stressed as well as its correlation with the main goal of the professional competences development.

Key words: distance education, distance learning system, higher education, goal setting, learning technologies, professional training, types of the distance education

\section{(статтю подано мовою оригіналу)}

Introduction. Modern higher education system in addition to full-time and correspondence types of education has recently developed a new form of education - distance learning. It has been conceived as a complex of educational technologies provided for a wide range of people through the creation of specialized computer and educational data by educational institutions [13].

The demand for the widespread introduction and development of distance learning is explained by the fact that traditional forms of education do not fully cope with the rapid information development and the increasing social need in modern educational technologies. The implementation of a distance education system based on computer, video, multimedia, and communication technologies permit to solve this problem effectively.

Nowadays distance education as a new type of learning technologies has arisen upon the request of a new generation of learners to support their needs. Therefore, distance learning involves the selection of educational methods not for the sake of obtaining an educational degree as a result of studying, but as a means of satisfying individual learners' needs.

Analysis of recent researches and publications. The place of distance education in modern education was highlighted in many publications. The problem of distance learning development in modern universities was described in the works of T. Anderson, V. Andrushchenko, R. Harrison, T. Desiatov, I. Ziaziun, M. Moore, D. Taylor, J. Hess, and others.

The issue of distance education implementation within the educational and virtual learning environment was studied by such Ukrainian and foreign scientists as O. Andreev, V. Lugovoi, S. Sysoeva, J. McQuaid and others. The problems of successful realization of distance education were also studied by B. Gershunsky, Y. Mashbits, I. Podlasy, didactic principles of distance learning communication were described by O. Rybalko, O. Sobaeva, and others.

Previously unsettled problem constituent. However, the analysis of scientific and pedagogical publications has demonstrated that modern tendencies of distance learning development in higher education institutions were not specifically considered by modern researches. Many researchers state that the issue of the place of distance learning in modern higher education is too broad and often controversial for timely scientific reports. Therefore, new publications highlighting the stated problem are important as a source of new scientific data for recording and further analysis.

Objectives. The introduction of computer communication technologies into the education system is probably the most significant change that has occurred in the global educational system in recent years. However, real changes provide only potential opportunities for the development of new educational technologies in higher institutions. The methods of traditional knowledge acquisition do not seriously suit either students or teachers. To determine the place of distance learning in the system of modern higher educational institutions, in this paper we try to identify the main aspects of distance learning technologies of goal setting for acquiring professional knowledge and competencies.

Results. European development of distance learning promoted by the Bologna Process and the Erasmus project allowed students from different countries to participate in online seminars and listen to any university course via the Internet, which made it possible for them to obtain education at several universities at the same time. New technologies have also promoted new possibilities for the Ukrainian students, as the distance learning facilities help to implement mobility and multimedia to the learning process. For many universities, distance learning has become a reality. Having entered the Bologna process, Ukraine got on a path of global reform of its higher education system, which should raise the status of national higher education diplomas in the European labor market.

Distance education can be defined as learning type, characterized by the following main points:

- Availability of two-side mutual agreement between the teacher and learner;

- Distance separation of the teacher and learner as well as the learners and educational institutions;

- Mutual two-directional interaction of the learners and teachers;

- Material selections designed specifically for distance learning.

For identifying the main goals of the distance education system, first of all, we should consider the main subjects of the educational process; outline its levels and boundaries, which make it possible to implement the distance education system in the professional training of modern higher educational institutions.

The range of various educational technologies plays a vital role in the development of practical mechanisms in educational functions provision. Educational institutions organize and support the educational process employing new methods and techniques, which have a decisive impact on the structure of the offered learning courses, and the segmentation of distance education.

The demand for different distance educational products by individual students is growing. The government, different enterprises, and organizations are also concerned with the quality of professional training provided through distance learning technologies. It should be noted that they have certain requirements for the content and quality 
of the educational process as a final user of educational services is a certain individual who should be able to carry the educational, professional and cultural potential for the benefits of the community and satisfying their own needs.

The fundamental need for the development of the range of educational technologies took place on demand of the educational system to comply with the socio-economic and industrial changes in the society. The ground for educational development is a socially organized mechanism that ensures a constant connection between producers and consumers of economically efficient benefits in the field of education [7; 16]. Thus, the educational technologies provide the process of knowledge and skills transferring for professional training, designed to enhance human potential and individual abilities for social self-realization, which makes it possible to define educational process as a system of economic relations between various individuals in order to provide appropriate educational outcomes, focused on developing personal abilities for producing economic growth.

The scientists distinguish educational technologies as something immaterial and intangible, which effectiveness is delayed in time and which quality is tested only in the process of consumption of the finished product when the graduates start working [12]. Educational technologies are dependent on people who implement them (the teaching staff of a professional institution) and its end-users; therefore, the main competitive advantage of any professional education institution is the level of the teaching staff qualification, which determines the quality of the educational process provided.

The result of education errors might be fatal for a final user; therefore, to ensure the quality of the educational process, the university must guarantee the obtaining of knowledge and skills that can satisfy the students' needs as well as the socio-economical demands. The delivery of an educational product is influenced by the unified education system of a higher institution and is provided to develop an individual's abilities, qualities, and motivation. Due to the significant time division between the educational process acquisition and obtaining the final results (professional skills and competencies), a direct assessment of the quality and sustainability of education is complicated.

Among the main goal-setting agents of the modern educational process in the first place, we should denote a direct user of educational technologies, whose interests and personal, professional, social aspirations, needs, and motivation are the guideline in the educational planning development. The next interested agent of educational technologies is the organization where the future professionals will work. It orders a professional training of an employee according to its special needs and functions, as well as the sets requirements to the specialists' level of competences. The third agent is the community with a certain system of guidelines and values corresponding to the cultural and historical development of the society.

The state that regulates the general level of education also puts forward special requirements in the form of an educational standard and carries out examinations as verification of specialist training compliance to a set educational level. An educational institution is one more agent of the modern educational process that fulfills the demand on the different education orders and develops educational plans based on its mission and educational goals.

The flexibility and adaptability of distance education and electronic educational programs permit to take these preconditions into account and change the content of professional training under the actual demands of individuals, organizations, community, and government.

Developing distance learning techniques it is necessary to consider different changes and new directions in modern education, which determine the trajectory of individual goals depending on an individual's existing level of skills and competences, personal and professional needs and the desired level of competences for short and longterm self-development. This approach permits to determine the main goals of the distance education system. In the framework of the intended trajectory of the individual's development, distance learning is carried out in three interrelated areas that determine learner's professional competences: educational, social, and professional. In other words, the goal-setting process is not limited only by educational prospects. A certain directional educational vector is being designed supporting the correlation between professional skills development and academic quasi-professional growth and professional education in general through the competences increase in solving professional problems.

The flexibility of the modern model of distance education exists since it could be defined as a four-stage model for professional competences development. They are the stage of knowledge or ontological, behavioral stage, stage of abilities, and personal or semantic stage.

Such a model of distance education is generated by a set of typical tasks and goals intended to be solved by professionals at a specific level of competence, and each typical task involves its fulfillment at the given stage of an individual's professional readiness. A stage selecting depends on the individual's learning progress: from knowledge through understanding to creative activity and next to the stage of personal professional development, when the learner's personal qualities and attitude to the chosen profession have been shaped.

A leading principle of the distance education system is the method of creative project design, which involves learners participating in the process of goal determination due to the interactive nature of online training materials and assignments. Every student is an individual, with his/her needs and motivation and should be involved in the educational plan development as an independent subject of the educational process. The educational planning and training materials for distance learning provide a special space for the individuals to complete the training program, fill it up with specific personal meanings and relevant goals, as well as personal experience and goals, social and professional needs. 
The educational planning is designed to provide an individual with an opportunity to apply their potential ensured by the training materials and supported by consulting assistance for individual needs and problems. At the same time, a learner receiving professional knowledge and skills is considered as a self-sufficient individual but is given a possibility to model own competences development [2].

Therefore, the distance education system for goal-setting acts as an innovative segment of education, characterized by the following features.

- Both the developers' and the learners' goals are presented in the training materials. These goals are not equal, but adequate to each other;

- The goals reflect the different educational, social and professional level of each learner;

- The process of setting goals depends on the future professional activities of a specialist and as a result of an assessment of his/her initial and achieved levels of competence;

- The goals are not imposed on learners and are not rigid, but are just suggested. In the distance education system, the goals represent a "horizon of possibilities" for an individual who has assessed his/her limitations can self-determine a personal development path;

- The training materials contain direct and indirect goals - through any set tasks, situations, and problems.

One of the main characteristic features of the distance education system is the emergence of new tasks during the educational program implementation through the principle of dynamic project design due to the existence of two goal-setting subjects: a learner competences development and a teacher as a developer of these competencies.

It should be noted that one of the shortcomings of the Ukrainian distance educational is a clear shortage of education specialists able to perform in an online teaching format. Modern distance education technologies have reached a level where their implementation requires highly qualified specialists for the development of techniques, motivation systems, and interactive models processing. At the designing of an educational course in distance learning, it is necessary to take into consideration the specific features of the distance education model, which attribute to the innovative forms of knowledge acquisition. One of the most distinguishing features of this model is the transparency of the boundaries between the educational, professional and social environments [5].

Nowadays innovative educational technologies and distance learning supplement and even gradually supersede such forms of education as correspondence and evening classes. These technologies greatly influence the development of modern professional training in universities, enriching it with new substantial and organizational components. The distance learning market is developing rapidly and is one of the most promising areas for the development of education in modern conditions.

Conclusions. Thus, the concept of competence inherent professional training should be conveyed to the educational process as the fundamental goal, which influences all educational goals setting respectively in developing the learner's knowledge, skills, and abilities. The correct and relevant goal setting in the distance education system makes it possible to build a multidimensional scale of values aimed at the development of professional competences in universities.

Wherein, the main requirements for the formulation of distance education goals and objectives are: instrumental, diagnostic, realistic, motivating and contextual. Learning goals should correspond to the context of the social and professional background of the future specialist and correlate with the main goal of competences development.

The cost of distance learning is cheaper than other forms of education, the learning time is less, and the speed of educational material acquisition is higher. As well as we should take into consideration a great number of specialists with a need of changing or improving their professional qualification for the reasons of the enterprises' shutdown or reprofiling, migration, and other when the distance learning is gaining more and more popularity.

However, the introduction of distance education technologies in modern universities is not simple as it requires the introduction and development of new teaching methods and specially designed materials for individual and independent studying in a holistic learning environment.

\section{References:}

1. Anderson T. \& Dron J. (2011). Three generations of distance education pedagogy. The International Review of Research in Open and Distributed Learning. № 12 (3). P. 80-97. URL: http://www.irrodl.org/index.php/irrodl/article/view/890.

2. Baran E., Correia A. P. \& Thompson A. (2011). Transforming online teaching practice: Critical analysis of the literature on the roles and competencies of online teachers. Distance Education. № 32 (3). P. 421-439. URL: https://www.tandfonline.com/doi/ $\mathrm{abs} / 10.1080 / 01587919.2011 .610293$ ?journalCode $=$ cdie20.

3. Beese J. (2014). Expanding learning opportunities for high school students with distance learning. American Journal of Distance Education. № 28 (4). P. 292-306. URL: https://www.tandfonline.com/doi/abs/10.1080/08923647.2014.959343.

4. Chavan A. \& Pavri S. (2004). Open-source learning management with Moodle. Linux Journal.

5. Conde M. Á., García-Peñalvo F. J., Rodríguez-Conde M. J., Alier M., Casany M. J. \& Piguillem J. (2014). An evolving Learning Management System for new educational environments using 2.0 tools. Interactive Learning Environments. № 22 (2). P. 188-204. URL: https://www.tandfonline.com/doi/abs/10.1080/10494820.2012.745433.

6. Fuller R. M., Vician C. \& Brown S. A. (2006). E-learning and individual characteristics: the role of computer anxiety and communication apprehension. The Journal of Computer Information Systems. № 46 (4). P. 103-15.

7. Guri-Rosenblit S. (2016). Distance higher education in the digital era: Challenges and prospects. Distance Education in China. № 6. P. 16-25.

8. Hung M. L. (2016). Teacher readiness for online learning: Scale development and teacher perceptions. Computers \& Education. № 94. P. 120-133. URL: https://www.sciencedirect.com/science/article/abs/pii/S0360131515300841?via\%3Dihub. 
9. Leonard J. \& Guha S. (2001). Education at the crossroads: online teaching and students' perspectives on distance learning. Journal of Research on Technology in Education. № 34:1. P. 51-58.

10. Keller J. M., Ucar H. \& Kumtepe A. T. (2017). Culture and Motivation in Globalized Open and Distance Learning Spaces. Supporting Multiculturalism in Open and Distance Learning Spaces. P. 146.

11. Meyer J. D., \& Barefield A. C. (2010). Infrastructure and administrative support for online programs. Online Journal of Distance Learning Administration. № 13 (3). P. 3.

12. Moore M. G., \& Kearsley G. (2011). Distance education: A systems view of online learning. Cengage Learning.

13. Regulations on distance learning. Order of the Ministry of Education and Science of Ukraine from 25.04.2013 № 466 [in Ukrainian]. URL: https://zakon4.rada.gov.ua/laws/show/z0703-13.

14. Zawacki-Richter O., \& Anderson T. (Eds.). (2014). Online distance education: Towards a research agenda. Athabasca University Press.

\section{Гавриленко К. М. Дистанційне навчання в сучасній системі вищяӧ освіти}

Дистанційна освіта є новим типом навчання, щзо з'явився на вимогу сучасного суспільства й завдяки розвитку нових комп'ютерних технологій. У статті визначається місце дистаниійного навчання в системі вищої освіти й основні переваги та недоліки впровадження технологій дистанційного навчання в розвитку професійних знань $і$ компетентностей. Також аналізується важливість отримання позитивних результатів дистанційного навчання для кінцевого користувача; окреслена роль професійного навчання дистанційного типу через набуття відповідних знань $i$ навичок для задоволення потреб людини, а також його сочіальні й економічні вигоди для суспільства. Наголошується на тому, що якість освіти залежить від єдиної уніфікованої системи вищого закладу, і на існуванні значного проміжку часу між здобуттям знань у прочесі навчання та його кінщевими результатами у формі розвитку професійних навичок і компетентностей.

Проаналізовано основні иілі планування дистанційної освіти як важливого засобу успішної професійної підготовки й підкреслено, щзо планування освіти має сприяти наданню можливості застосувати ї̈ потенціал, підкріплений навчальними матеріалами та відповідною консультаційною допомогою. Визначено основні вимоги до постановки цілей $і$ завдань дистанційної освіти й наголошено на важливості відповідності навчальних иџілей соціальному та професійному статусу майбутнього фахівия.

Ключові слова: види дистанціийної освіти, вища освіта, дистанційна освіта, постановка иілей, професійна підготовка, система дистаниійного навчання, технологї навчання.

\section{УДК 37.01}

DOI https://doi.org/10.31392/2311-5491/2019-70.14

Гагарін М. I.

\section{ВПЛИВ ТРАДИЦЙ ТА ІННОВАЦІЙ НА РОЗВИТОК І ФУНКЦІОНУВАННЯ ВИХОВНОЇ СИСТЕМИ ЗАКЛАДУ ЗАГАЛЬНОЇ СЕРЕДНЬОЇ ОСВІТИ}

У статті проаналізовано значення традииій та інновацій у становленні й розвитку виховних систем закладів загальної середньої освіти в сучасних умовах.

Мета статті полягає у визначенні й аналізі впливу традицій та інновацій на розвиток виховних систем закладів загальної середньої освіти.

Висвітлено сутність понять «традиція», «інновація»; інноваџійний потениіал виховної системи трактується як здатність «сприймати» та реалізовувати інновації на рівні виховних нововведень загалом і щодо конкретної інновачії.

Виховна система школи інтерпретується як комплекс взаємопов'язаних і взаємовизначених основних компонентів (иілей, заради яких система створюється; учнів як суб 'єктів спільної діяльності; освоєного ними середовища; взаємин, що виникають між учасниками діяльності; управління; самоуправління), щзо забезпечує розвиток і самореалізацію особистості в проиесі ї̈ функціонування.

Наголошується, що визначальне значення в упровадженні інновачій належить учасникам системи (учнівський і педагогічний колективи); провідну роль відіграє інновачійність середовища, особливості управлінської та самоуправлінської діяльності.

Зроблено висновки, щчо феномен виховної системи школи є складним і багатогранним явищем; гуманістична спрямованість системи та відповідність інноваџій і традиџй інтересам учня уможливлюють розв 'язання проблеми розвитку особистості.

Матеріали дослідження можуть бути використані в процесі створення й розвитку виховної системи школи.

До перспективних напрямів дослідження иієї проблеми належить, зокрема, вивчення вітчизняного та зарубіжного досвіду впровадження інновацій у виховну систему й перетворення найоптимальніших із них у традииії.

Ключові слова: система, виховна система, виховна система закладу загальної середньої освіти, інноваційний потениіал виховної системи, традииія, інновація, традииї виховної системи, інновації виховної системи.

Розв'язання проблем виховання особистості потребує взаємодії всіх учасників виховного процесу, системного впливу на особистість, власне, побудови та розвитку виховної системи закладу загальної середньої освіти. Функціонування будь-якої соціальної системи передбачає ії цілісність, упорядкованість, певну стандартизацію й уніфікацію, що значною мірою відображається в традиціях; водночас зміна поколінь учасни- 